\title{
Computer Modeling of Second-Order Recursive Digital Filters of the Automated Design Signaling System
}

\author{
Vasyl Stefanyk Precarpathian National University, 57 Shevchenko St., Ivano-Frankivsk, 76000, Ukraine
}

In the article the analytical method of modeling software recursive digital filters of the second order with zeros on the circle of the single radius is presented. The corresponding algorithm of scaling of this composition of filters for signal CAD is developed.

Article acted received 26.06.2017; accepted for publication 05.12.2017.

\section{Introduction}

The task of the proposed method of processing the signal CAD will be to show the need for the development of recursive digital filters (RTSF) with a redesigned structure. The values contained in the main calculation and synthesis of programmable digital filters are mainly determined by the kind of reconfiguration of the parameters. Here, respectively, distinguish large-scale and non-large-scale reconfiguration of the parameters of amplitude-frequency characteristics (AFC, or hodograph). Often used in the development of programmed as transversal and recursive digital filters

large-scale reconfiguration, which changes the zoom settings:

- cut-off frequency $\psi 3$ for low-pass filter (LPF) filters and high-frequency filters (high-frequency); - the central frequency $\psi 0$ and the bandwidth $\Delta \psi$ for bandpass filters (SF), herewith Q remains constant; - Analog filters are the basic basis for digital filters.

\section{Theory and methodology}

Programmable recursive digital filters of the first and second order assign the role of base units in cascade and parallel structures of higher orders $(\geq 3)$. Here the most versatility is the two-square block, which allows to be realized on the basis of one special calculator of LPF, high-frequency, and band or recursive filter. The transfer function (characteristic) of the second order is defined as follows:

$$
\mathrm{H}(\mathrm{z})=\mathrm{B}_{0} \frac{1+B_{1} Z^{-1}+B_{2} Z^{-2}}{1+A_{1} Z^{-1}+A_{2} Z^{-2}},
$$

where $\mathrm{B}_{0}$ is the scaling factor, $\mathrm{Ai}, \mathrm{Bi}(\mathrm{i}=0,1,2)$ is the $\mathrm{Z}$-position filter of the $\mathrm{z}$-transformation variables.
In this paper, analytical expressions for calculating (simulating) the coefficients of the transfer function of programmable RTSF are the exact method based on analog filters. This is due to the fact that today very well-designed and well-studied methods for the synthesis of analogue filters and there is an important reference material for different types of approximation. In this case, the calculations of the coefficients of the function $\mathrm{H}(\mathrm{z})$ from the transfer function of the analog prototype from the rational form of the transformation operator of the p-region to the z-domain.

\section{Practical application}

The use of analog prototype allows the basis of bilinear $\mathrm{z}$-transform to obtain the following expressions for analytical modeling: - for digital LPF B1 $=2$.

$$
\mathrm{A}_{1}=\frac{\Omega_{A}^{2}\left(\Omega_{A}^{2}\left(2 x^{2}+1\right)-2\right.}{\Omega_{A}^{2}\left(x^{2}+0,5\right)+\sqrt{2} x \Omega_{A}+1}
$$

$$
\begin{aligned}
& \mathrm{A}_{2}=\frac{\Omega_{A}^{2}\left(x^{2}+0,5\right)-\sqrt{2} x \Omega_{A}+1}{\Omega_{A}^{2}\left(x^{2}+0,5\right)+\sqrt{2} x \Omega_{A}+1} ; \\
& - \text { for digital FBCH B1 }=-2 \\
& \quad \mathrm{~A}_{1}=\frac{2-\Omega_{B}^{-2}\left(\Omega_{B}^{2}\left(2 x^{2}+1\right)\right.}{\Omega_{B}^{-2}\left(x^{2}+0,5\right)+\sqrt{2} x \Omega_{B}^{-1}+1}, \\
& \mathrm{~A}_{2}=\frac{\Omega_{B}^{-2}\left(x^{2}+0,5\right)-\sqrt{2} x \Omega_{B}^{-1}+1}{\Omega_{B}^{-2}\left(x^{2}+0,5\right)+\sqrt{2} x \Omega_{B}^{-1}+1} ;
\end{aligned}
$$

where $\quad x=\operatorname{sh}\left[0,5 \operatorname{ars}\left(10^{0,1 \Delta n}-1 f^{\psi / 2}\right] ; \quad \Omega_{A}=\operatorname{tg} \pi \psi_{A}^{\prime}\right.$; $\Omega_{B}=\operatorname{tg} \pi \psi_{B}^{\prime} \quad ; \quad \psi_{A}^{\prime}=\frac{\psi_{A}}{\psi_{D}} \quad ; \quad \psi_{B}^{\prime}=\frac{\psi_{B}}{\psi_{D}}$ here $\Delta$ n-inequality of the AFC of the RSH in the bandwidth $\partial \mathrm{B} ; \psi_{-} \mathrm{A}, \psi_{-} \mathrm{B}-$ cutoff frequencies of digital LPF and HF, respectively $\psi_{-}$D- sampling frequency;

$$
\begin{array}{cccc}
\text { - for } & \text { bandpass } & \text { filters } & \mathrm{B}_{0}=0 \\
\mathrm{~A}_{1}=\frac{2\left(\Omega_{0}^{-2}-1\right)}{1+\frac{\omega}{\varepsilon}+\Omega_{0}^{2}} & & \text { (4) }
\end{array}
$$




$$
\mathrm{A}_{2}=\frac{1-\frac{\omega}{\varepsilon}+\Omega_{0}^{2}}{1+\frac{\omega}{\varepsilon}+\Omega_{0}^{2}},
$$

where $\mathrm{d}=[10 \Omega \wedge(\Delta \mathrm{n} / 20)$ is the approximation plane

$$
\begin{gathered}
\varepsilon=\frac{\sqrt{1-d^{2}}}{d^{2}}, \Omega_{0}^{2}=\operatorname{tg}\left(\frac{\pi \psi_{1}}{\psi_{D}}\right) \operatorname{tg}\left(\frac{\pi \psi_{2}}{\psi_{D}}\right), \\
\omega=\operatorname{tg}\left(\frac{\pi \psi_{2}}{\psi_{D}}\right)-\operatorname{tg}\left(\frac{\pi \psi_{1}}{\psi_{D}}\right) .
\end{gathered}
$$

Solving the equation (1) with respect to $\Delta \mathrm{n}, \psi_{-} \mathrm{A},(2)$ with respect to $\Delta \mathrm{n}, \psi_{-} \mathrm{V}$, we obtain the following calculation expressions:

$$
\begin{aligned}
& \Delta \mathrm{n}=10 \lg \left(\operatorname{sh}^{2}\left(2 \operatorname{arsh} \frac{1-A_{2}}{\sqrt{6 A_{2}-A_{2}^{2}-A_{2}^{2}-1}}\right)+1,\right. \\
& \psi_{A}^{\prime}=\frac{1}{\pi} \operatorname{arctg} \frac{2 \sqrt{6 A_{2}-A_{2}^{2}-A_{2}^{2}-1}}{\sqrt{2}\left(A_{2}-A_{1}-1\right)}, \\
& \psi_{B}^{\prime}=\frac{1}{\pi} \operatorname{arctg} \frac{2 \sqrt{6 A_{2}-A_{2}^{2}-A_{2}^{2}-1}}{\sqrt{2}\left(A_{2}+A_{1}+1\right)} .
\end{aligned}
$$

Since $\Delta \mathrm{n}, \psi_{-} \mathrm{A} \wedge{ }^{\wedge}, \psi_{-} \mathrm{B}^{\wedge^{\prime}}$ are positive numbers, then from equation (1) and (2) the restrictions on the quantities $\mathrm{A} 1$ and $\mathrm{A} 2$ are executed.

$$
\begin{gathered}
\mathrm{A}_{2}-\mathrm{A}_{1}+1>0, A_{1}^{2}-4 \mathrm{~A}_{2}>0,1-\mathrm{A}_{2}>0, \\
\mathrm{~A}_{2}+\mathrm{A}_{1}+1>0
\end{gathered}
$$

The domain of constraints (6) is interpreted here as an area on a plane with rectangular coordinates A1 and A2, which is limited by a triangle whose vertices are placed at $(-2.1),(2.1),(0,-1)$. This region of stability of the filter is divided into two parts by the parabola A2A_1 $\wedge^{\wedge} 2 / 4$ : the weak damping region $\left(\left(A \_1 \wedge 2\right) / 4<A \_2\right.$ $<1)$ and the region of strong damping $\left(-1<\mathrm{A} 2<\mathrm{A} \_1 \wedge 2\right)$. In the case of the implementation of LPF and highfrequency control of the frequency of growth it is expedient to perform in the first area close to the parabola, that is, when fast damped self-oscillations of the filter are allowed. Thus, the region of the analysis of the frequency response (or the hodograph) is limited by the inequalities: $-2<\mathrm{A},<2,0<\mathrm{A} \_2<1$.

The structure of the program of automated analysis of ACL $(\mathrm{FCH})$ is considered by the example of the LPF. It requires the following blocks of the algorithm: a) Enter the value of the sampling frequency $\psi_{-} D$ and the initial frequency of the analyzing area $\psi_{-} 0$, the analysis $\Delta \psi$, the value of the coefficients $\mathrm{A} 1$ and $\mathrm{A} 2$; b) calculation of the values of the frequency response $\mathrm{H}$ $(\varphi), \varphi=2 \pi(\varphi 0+\operatorname{and} \Delta \varphi) / \varphi \mathrm{D}, \mathrm{i}=1,2 \ldots \mathrm{n}$; c) check the frequency response on the existence of extremums in the selected frequency range; d) search in the array $\mathrm{H}$ ( $\varphi \mathrm{i}$ ) of the maximum and minimum values and memorizing the corresponding frequencies;

e). search in the array $\mathrm{H}\left(\varphi_{0}\right)$ of the point $(A \omega \varepsilon \varphi-3) d B$ in the interval $D>\varphi>\varphi_{0}$; e) calculation of the unevenness of the frequency response;

g). output to the screen of output data and analysis results.

The analysis shows that programmable digital filters that are implemented as a base link with zeros of the transfer function located on the circle of the single radius, retain sufficiently wide possibilities for reordering the frequency response by changing the coefficients A1 and A2. The cutoff frequency of the LPF can be adjusted, for example, with $\varphi \mathrm{D}=$ const and $\Delta \mathrm{H}<3 \mathrm{~dB}$, if you select $\mathrm{A} 2=0.5-0.55$, and the coefficient A1 varies within $-1,2$ $<\mathrm{A} 1<0$. In doing so, you must fulfill the condition of scaling $\mathrm{Hmax}=0$ by changing the multiplier B0 within (4-30) dB. Adjusting the frequency of the high-frequency cut-off at the same opportunity on $\varphi \mathrm{D}$ and $\Delta \mathrm{H}$ is possible within the limits and for this purpose it is necessary to choose the coefficient $\mathrm{A} 2=0.4-0.45$ and to find the second coefficient within $-1.2<\mathrm{A} 1<1 ., 2$, choosing for each pair (A1 and A2 ᄀ) is the scaling factor B0, due to which the Hmax varies from magnitude from $14.4 \mathrm{~dB}$ to 21.0dB.

The performed algorithm of calculation was used in hardware implementation of the program RTSP, where the 10-bit coefficients of the transfer function were used, and the number of operators within the calculator was equal to 12. Comparing the results of the experiment with theoretical calculations shows the high adequacy of this computer simulation.

\section{Conclusions}

1. An algorithm for computer modeling of recursive digital filters (LPF, HF, SF) is developed.

2. Using the scale factor B0, an algorithm for scaling RTSP is executed.

3. The developed algorithm of modeling determines the signal of CAD digital filtering.

Novosyadly S.P. - doctor of technical sciences, professor of the department of computer engineering and electronics;

Valter R. . - student.

[1] Je. Ajficher, B. Dzhervis, Cifrovaja obrabotka signalov. Prakticheskij pohod (Vil'jams, Moskva, 2004).

[2] A. Anton'ju, Cifrovye fil'try: analiz i proektirovanie (Radio i svjaz', Moskva, 1983).

[3] R. Blejhut, Bystrye algoritmy cifrovoj obrabotki signalov: Per. s angl. (Mir, Moskva, 1989).

[4] V.I. Bondarev, G. Trjoster, V.S. Chernega, Cifrovaja obrabotka signalov: Metody i sredstva. Ucheb. posobie dlja vuzov. 2-e izd.(Konus, Har'kov, 2001).

[5] A.S. Glinchenko, A.I. Golenjuk, Principi organizacii i programmirovanija signal'nyh processorov ADSP21HH (Izd-vo KGTU, Krasnojarsk, 2000).

[6] L.M. Gol'denberg i dr., Cifrovaja obrabotka signalov: Uchebnoe posobie dlja vuzov (Radio i svjaz', Moskva, 1990).

[7] V.S. Gutnikov, Fil'tracija izmeritel'nyh signalov (Jenergoatomizdat, Leningrad, 1990). 
[8] D. Dadzhion, R. Mersero, Cifrovaja obrabotka mnogomernyh signalov (Mir, Moskva, 1988).

[9] V.I. Dmitriev, Prikladnaja teorija informacii: Uchebnik dlja studentov vuzov (Vysshaja shkola, Moskva, 1989).

[10] V. D'jakonov, I. Abramenkova, MATLAB. Obrabotka signalov i izobrazhenij. Special'nyj spravochnik (SPb.: Piter, 2002).

[11] A.V. Oppengejm, R.V. Shafer, Cifrovaja obrabotka signalov (Svjaz', Moskva, 1979).

[12] R.V. Hemming, Cifrovye fil'try (Nedra, Moskva, 1987).

[13] V. Shrjufer, Obrobka signaliv. Pidruchnik / za red. V.P. Babak (Libid', Kiev, 1992).

С.П. Новосядлий , Р.В. Вальтер

\section{Комп'ютерне моделювання рекурсивних цифрових фільтрів другого порядку сигнальної системи автоматизованого проектування}

Прикарпатський національний університет імені Василя Стефаника, вул. Шевченка 57, м. Івано-Франківськ, 76000, Україна, е-mail: rom.valter2013@ meta.ua

В статті викладений аналітичний метод моделювання програмних рекурсивних цифрових фільтрів другого порядку з нулями на колі одиничного радіуса. Розроблено відповідний алгоритм масштабування даного складу фільтрів для сигнальної системи автоматизованого проектування (САПР). 